\title{
Operationalisation of Safety Culture to Foster Safety and Health in the Malaysian Manufacturing Industries
}

\author{
Noor Aina Amirah ${ }^{1}$, Wan Izatul Asma ${ }^{1,2}$, Shaladdin Muda ${ }^{1} \&$ Aziz Amin ${ }^{3}$ \\ ${ }^{1}$ Faculty of Management and Economics, Universiti Malaysia Terengganu, Malaysia \\ ${ }^{2}$ Institute of Oceanography and Environment, Universiti Malaysia Terengganu, Malaysia \\ ${ }^{3}$ Faculty of Islamic Contemporary Studies, Universiti Sultan Zainal Abidin, Malaysia \\ Correspondence: Wan Izatul Asma, Institute of Oceanography and Environment, Universiti Malaysia Terengganu, \\ Malaysia. Tel: 60-9-668-3620. E-mail: wia@umt.edu.my
}

Received: March 6, 2013 Accepted: April 15, 2013 Online Published: June 1, 2013

doi:10.5539/ass.v9n7p283 URL: http://dx.doi.org/10.5539/ass.v9n7p283

\begin{abstract}
Rapid economic growth via industrialization has given not only a significant impact in terms of income distributions and quality of life, but it also resulted in increasing number of accidents at workplace. In reducing risk at the workplace, Occupational Safety and Health (OSH) is an important aspect. It is a standard which are set in legislation with the aim to eliminate and reduce hazards at workplace. Besides OSH, the term 'safety culture' is also an important aspect in reducing risk and accident at workplace. This paper discuss on the operationalisation of safety culture to foster safety and health for the Malaysian manufacturing industries. Operationalisation is the process of specifying the extension of a concept which in turn, will convert the concept into a measure. Hence, operationalisation will make possible concept to be uniformly understood and used since no measurement has ever been established to determine the current state of safety culture in the Malaysian manufacturing industries. A methodology quantitative was adopted towards a comprehensive understanding of safety culture amongst operational workers in Malaysian manufacturing industries. The preliminary survey has identified management commitment, safety leadership, training and education and employees involvement as important behavioral aspects. The findings generated from selected operational workers in Malaysian manufacturing industries reveal that safety culture comprises of both the behavioral and situational aspects. These identified behavioral aspects were further included in the main survey and combined with situational aspects towards safety culture in manufacturing industries. At the end, this study is expected to help policy makers and government to formulate new, effective and efficient policies and strategies that will promote a safety and health working environment, which in turn will be a workplace culture in this sector.
\end{abstract}

Keywords: operationalisation, safety and health, safety culture, Malaysian manufacturing industries

\section{Introduction}

Rapid economic growth via industrialisation has given not only a significant impact in terms of income distributions and quality of life, but it also resulted in increasing number of workplace accidents. To reduce risk at the workplace, Occupational Safety and Health (OSH) is an important standard which are set in legislation with the aim to eliminate and reduce hazards at workplace. Apart from OSH, the term 'safety culture' is also an important aspect in reducing risk and accident at workplace.

Safety culture can be viewed as a component of the organizational culture that refers to the individuals, jobs and organizational characteristics that affect employees' health and safety (Fernandez-Muniz, Montes-Peon \& Vazquez-Ordas, 2007). There were increasing interests among researchers and practitioners since the past two decades towards the concept of safety culture because of its impact on safety outcomes such as injuries, fatalities, and other incidents (Choudhry, Fang \& Mohamed, 2007). The aim of safety culture is to avoid taking any unsafe actions (Fernandez-Muniz et al., 2007). According to the Malaysian Department of Occupational Safety and Health (DOSH, 2010), the International Labour Organisation (ILO) Safety Culture Model has identified different levels of safety culture. These levels of safety culture are influenced by three main independent variables namely:

1) Individual's commitment 
2) Managers' commitment

3) Policy commitment

Since no accepted framework has been established to analyse safety culture in the Malaysian manufacturing industries, this research will be a pioneer research that will determine the factors or characteristic of safety culture in this industry. The framework developed in this research will be tailored towards the operationalisation of the concept of safety culture in the Malaysian manufacturing industries. Hence, it will allow safety culture to be uniformly understood and used by all interested parties to inculcate safety culture (Ismail, Hashim, Ismail \& Majid, 2009).

Operationalisation is the process necessary to establish an 'operational definition' that will allow a concept or construct to be uniformly understood and used by all interested parties (Tustin, 1992). An operational definition assigns meaning to a construct or a variable by specifying the activities or operation necessary to measure it (Kerlinger, 1973). Therefore, operationalisation is the process of specifying the extension of a concept which in turn, will convert the concept into a measure. This measure can be a variable, constant or scale depending upon the situation (Ismail et al., 2009). Operationalisation is valuable if used properly. It is aimed at establishing ideal structures and offering definitions that estimate the concept included in the research. It is an indispensable tool of quantitative but its methodological should not be overestimated (Sarantakos, 1998).

According to Martyn (2008), operationalisation is the process of strictly defining variables into measurable factors. This operationalisation process defines fuzzy concepts and allows them to be measured, empirically and quantitatively. There are 3 stages of operationalisation with four major steps according to Martyn (2008) as shown in Figure 1.

\begin{tabular}{|c|c|c|c|c|}
\hline $\begin{array}{c}\text { Stage 1 } \\
\text { Question about } \\
\text { the big picture }\end{array}$ & $\begin{array}{l}\text { Question about } \\
\text { the big picture }\end{array}$ & Population & $\begin{array}{c}\text { Hypothetical } \\
\text { Theories / } \\
\text { Concepts }\end{array}$ & $\begin{array}{l}\text { Theory } \\
\text { Literature } \\
\text { Review } \\
\text { Scientists' } \\
\text { Thoughts }\end{array}$ \\
\hline $\begin{array}{c}\text { Stage } 2 \\
\text { Choosing } \\
\text { Design and } \\
\text { Method }\end{array}$ & $\begin{array}{l}\text { Defining a } \\
\text { Research } \\
\text { Problem }\end{array}$ & Sampling & $\begin{array}{l}\text { Choosing } \\
\text { Indicators }\end{array}$ & Creating Study \\
\hline $\begin{array}{c}\text { Stage } 3 \\
\text { Data Collection }\end{array}$ & $\begin{array}{c}\text { Testable, } \\
\text { Narrow } \\
\text { Hypothesis } \\
\text { (Prediction) }\end{array}$ & Sample & $\begin{array}{c}\text { Observable, } \\
\text { Measurable } \\
\text { Variables }\end{array}$ & $\begin{array}{l}\text { Specific } \\
\text { Situation }\end{array}$ \\
\hline
\end{tabular}

Figure 1. Operationalisation process

Based on Figure 1, there are four major steps in operationalisation namely:-

1) Defining a research problem - what the researcher believes to be the main issue surrounding the problem

2) Sampling - portion of elements in the population selected to represent the population under study

3) Choosing indicator - identification of the factors' characteristics

4) Creating study - conduct in depth study in specific situation

\section{Research Methodology}

The approach of this study used the Operationalisation Model as suggested by Martyn (2008) in the following manner:-

\subsection{Step 1: Defining a Research Problem}

OSH was chosen as a main issue in this study since workplace accident cases has come into government concern these recent years. According to the International Labor Organization (ILO), it is estimated about 2 million workers are killed due to work-related accidents and diseases, 270 million occupational accidents and 160 
million work-related diseases are occurring annually (Soehod \& Laxman, 2007). Based on the statistic of occupational accidents by sector in 2011, as endorsed by the Malaysian Department of Occupational Safety and Health (DOSH), it shows that manufacturing is the highest sector with non-permanent disabilities (NPD) and permanent disabilities (PD) due to occupational accidents - 1471 workers suffered NPD while 133 workers suffered PD (DOSH, 2012).

\subsection{Step 2: Sampling}

By using sampling method, 30 operational workers in an identified manufacturing organisation were randomly chosen as sample size for this preliminary study. This sample size was chosen since the rule of thumb for pilot study must be 30 or greater (Browne, 1995).

\subsection{Step 3: Choosing Indicator}

The selection of indicators involved the identification of the factors' characteristics for safety culture which was based on the review of safety culture from previous research.According to Mohd Saidin et. al (2006) and Krause and Weekley (2005), there are 12 elements of safety culture namely:-

1) Organizational Structure

2) Management Commitment

3) Employees' Involvement

4) Behavioural Changes

5) Safety Policy

6) Training and Education

7) Safety Committee

8) Motivation

9) Groupwork

10) Working Environment

11) Empowerment

12) Safety Leadership

Adopting from Bandura's model of reciprocal, Cooper (2000) developed a Reciprocal Safety Culture Model. This model contains three elements namely:-

1) Psychological factors

Person refers to internal psychological factors which concerns on individual or personal factors such as attitudes, perceptions, beliefs and values.

2) Behavioural factors

Behaviour refers to individual behaviour such as leadership style, number of safety training attends, inspections, safety audits etc.

\section{3) Situational factors}

Situation refers to the workplace situation such as organization policies, operating procedures, management system, communication flows and workflows.

Ismail, Harun Ismail \& Majid (2010) has adopted Cooper's model in the development of a framework for promoting safety culture for the Malaysian construction companies. The framework includes three components: psychological (values and beliefs), behavioral (leadership, organizational commitment, management commitment, training and resource allocation), and situational (internal and external). The internal factor comprise of safety management system while external factor comprise of industry norms, government policies and regulations and economic climate.

However, this study took into account only two aspects that will lead to positive safety culture which are behavioural and situational aspect. Behavioural aspects refer to management commitment, safety leadership, training and education and employees involvement while situational aspect refers to safety compliance. In this study, it is believed that preparing a good medium (behavioral and situational) is important for any authorised body or government agencies to having positive safety culture in manufacturing industries. Employees' belief and attitudes (personal characteristic) will come later, in line with the good preparation of behavioral and 
situational aspects.

\section{Creating Study}

In depth study will be conducted based on chosen indicator in the identified situation.

This research employed a quantitative study method. According to Mohd Saidin et. al (2006) and Krause (2005), there are 12 elements of safety culture as follows:-

1) Organizational Structure

2) Management Commitment

3) Employees' Involvement

4) Behavioral Changes

5) Safety Policy

6) Training And Education

7) Safety Committee

8) Motivation

9) Workgroup

10) Working Environment

11) Empowerment

12) Safety Leadership

Based on these 12 elements, review of the study from 15 researchers has been conducted. Based on the reviews, it can be concluded that four important elements in safety culture were safety leadership, management commitment, employees' involvement and training and education. Table 1 shows the reviews of these 12 elements.

Table 1. Summary of safety culture characteristic review

\begin{tabular}{|c|c|c|c|c|c|c|c|c|c|c|c|c|}
\hline Authors & O.S & M.C & E.I & B.C & S.P & $\mathrm{T} \& \mathrm{E}$ & S.C & M & $\mathrm{W}$ & W.E & $\mathrm{E}$ & SL \\
\hline Muniz et. Al (2007) & & 1 & 1 & & & & & & & & & \\
\hline Piers et. Al (2009) & & l & & & & & & & & & & \\
\hline Rosa (2010) & & & & & & & & & & & & / \\
\hline Taubits (1992) & & l & & & & & & & & & & \\
\hline Swartz (1992) & & l & & & & & & & & & & \\
\hline Duke (1997) & & & & & & & l & & & & & \\
\hline Turner (1991) & & & & & l & & & & & & & l \\
\hline Reason (1997) & & & & & & l & & & & & & \\
\hline Ek et.al (2006) & & & & l & & / & & & & l & & l \\
\hline Wu et. Al (2009) & & & / & & & & & & & & & \\
\hline Hale (2000) & & & / & & & & & & & & & / \\
\hline Vecchio (2004) & & l & I & 1 & & l & & & & & & \\
\hline Choudhry et .all (2007) & & / & & & & & & & & & / & / \\
\hline Faridah et. All (2010) & & l & & & & l & & & & & & / \\
\hline Saidin et. All (2008) & & & / & & l & l & / & l & / & / & & l \\
\hline TOTAL & - & 7 & 5 & 2 & 2 & 5 & 2 & 1 & 1 & 2 & 1 & 7 \\
\hline
\end{tabular}

A preliminary survey was conducted in this study by using 30 operational workers from one selected manufacturing industry in Terengganu. This preliminary survey was conducted to capture the behavioural dimension of the safety culture. The first part of the questionnaire was designed to capture the background of the 
respondents and the company. These include respondents' gender, age, working years, injury experience and safety training experience. The second part of the questionnaire was designed to enable responses to identify safety culture within the organisation.

It is important to know the pattern of their involvement and the background of the organisation as culture can arise from the learning experiences as their organisations evolve (Schneider, 1990). The last part in this questionnaire was designed to capture the behavioural and situational dimension of the safety culture in the manufacturing industries. Both second and third part of this questionnaire were measured using a 5 point Likert scale (namely very poor, poor, moderate, good, excellent) which were subjected to the interpretation of the respondents.

The Statistical Packaging for Social Science (SPSS) version 16.0 was used to complete the data analysis. The initial process was to check the normality of the data set. In this study, only a measure of skewness is used to check the normality of the data set. The data is perfectly normally distributed if the measure of skewness is 0.0 but the measure between (-1.0) and 1.0 is considered normally distributed (Zainudin, 2010). The second statistical technique used is reliability analysis. The popular measure of reliability is the Cronbach's alpha. Nunally (1978) suggests that the minimum value of Cronbach's alpha is 0.6 which will reflect the measuring factors.

\section{Findings and Discussions}

The respond rate of the preliminary study was $100 \%$. The result of each element was presented in Table 2 . As illustrated in this table, the skewness of 'safety culture' was $(-0.354)$. The skewness of management commitment was $(-0.812)$, safety leadership (-0.236), training and education $(-0.019)$ and employees' involvement $(-0.249)$ which represent behavioral dimension while the skewness of safety compliance which represent situational dimension was (0.394). This result of the normality test can be considered as normally distributed and can be proceed for further analysis since the measure of skewness between $(-1.0)$ and 1.0 is considered as normally distributed.

Table 2. Summary of the result of normality test

\begin{tabular}{lccccccc}
\hline \multicolumn{1}{c}{ Element } & $\begin{array}{c}\text { No. of } \\
\text { Sample }\end{array}$ & $\begin{array}{c}\text { Minimum } \\
\text { Score }\end{array}$ & $\begin{array}{c}\text { Maximum } \\
\text { Score }\end{array}$ & Mean & $\begin{array}{c}\text { Std. } \\
\text { Error }\end{array}$ & $\begin{array}{c}\text { Std. } \\
\text { Deviation }\end{array}$ & Skewness \\
\hline Safety Culture & 30 & 1.83 & 5 & 3.6306 & 0.11106 & 0.60832 & -0.354 \\
Management Commitment & 30 & 1.33 & 5 & 3.5852 & 0.16863 & 0.92362 & -0.812 \\
Safety Leadership & 30 & 1.67 & 5 & 3.3556 & 0.16012 & 0.877 & -0.236 \\
Training and Education & 30 & 2.11 & 5 & 3.6556 & 0.1279 & 0.70051 & -0.019 \\
Employees' Involvement & 30 & 1.67 & 5 & 3.463 & 0.12219 & 0.66927 & -0.249 \\
Safety Compliance & 30 & 2.57 & 5 & 3.6738 & 0.10493 & 0.57471 & 0.394 \\
\hline
\end{tabular}

As shown in Table 3, the Cronbach's alpha for safety culture comprises of 12 items was 0.820 . The coefficient reliability of management commitment which comprises of nine items was 0.924 while safety leadership which comprises of 12 items was 0.931 . Training and education and employees' involvement, both of which comprise of 9 items have coefficient of 0.881 and 0.849 respectively. The Cronbach's alpha for safety compliance factor comprises of 14 items was 0.863 . It is important to know that all factors have provided a reliable measure of internal consistency since all reliability measure have exceeded the minimum value of 0.6 as recommended by Nunally (1978). 
Table 3. Summary of the result of reliability statistics

\begin{tabular}{lccc}
\hline \multicolumn{1}{c}{ Element } & $\begin{array}{c}\text { Number of items in an } \\
\text { element }\end{array}$ & $\begin{array}{c}\text { Cronbach's } \\
\text { Alpha }\end{array}$ & $\begin{array}{c}\text { Cronbach's Alpha based on } \\
\text { standardized items }\end{array}$ \\
\hline Safety Culture & 12 & 0.82 & 0.818 \\
Management Commitment & 9 & 0.924 & 0.925 \\
Safety Leadership & 12 & 0.931 & 0.931 \\
Training and Education & 9 & 0.881 & 0.885 \\
Employees' Involvement & 9 & 0.849 & 0.845 \\
Safety Compliance & 14 & 0.863 & 0.866 \\
\hline
\end{tabular}

Therefore, based on this preliminary study, the findings generated from selected operational workers reveal that safety culture comprises of both the behavioural and situational aspects. This data set can be used in the main survey to conduct further study

\section{Conclusion}

This paper set out the elements involved for the operationalisation of safety culture. The approach involved four steps as suggested by Martyn (2008) where one step was defining a research problem when the researcher identified the main issue surrounding the problem. This was done by conducting literature review and by relying on accident statistics reported at workplace published by the Department of Occupational Safety and Health (DOSH). Step two was the sampling where 30 operational workers were randomly selected from a manufacturing organisation in Terengganu in this preliminary study. The third step was choosing the indicator where the characteristic of safety culture were identified within qualitative and quantitative techniques. The last step would be conducting a study which will be done based on the indicator identified.

From the above finding, it can surmised that the operationalisation of safety culture for the Malaysian manufacturing industries which was mainly adopted from Coopers' Safety Culture Model isolated the psychological factor and considered only the behavioural and situational factors. These behavioural factors were measured by management commitment, safety leadership, training and education and employees' involvement while situational factors were measured by safety compliance to government regulations. These specific characteristics of safety culture in manufacturing industries have not been explored by any other researcher in Malaysia and, therefore, this study will contribute to the development of safety culture in this sector in the future. After the study is concluded, it is expected to help policy makers and related government departments to formulate new, effective and efficient policies and strategies that will promote a safety and health working environment, which in turn will be a workplace culture in this sector.

\section{References}

Browne, R. H. (1995). On The Use of a Pilot Sample for Sample Size Determination. Statistics in Medicine, 14, 1933-1940. http://dx.doi.org/10.1002/sim.4780141709

Choudhry, R. M., Fang, D., \& Mohamed, S. (2007). The Nature of Safety Culture: A Survey of the State-of-the-art. Safety Science, 45, 993-1012. http://dx.doi.org/10.1016/j.ssci.2006.09.003

Cooper, M. D. (2000). Towards a Model of Safety Culture. Safety Science, 36, 111-136. http://dx.doi.org/10.1016/S0925-7535(00)00035-7

DOSH. (2010). The Role and Development. Retrieved from http://www.dosh.gov.my/doshv2/index.php?option=com_content\&view=article\&id=84\%3Athe-role-and-de velopment\&catid $=39 \% 3$ Adosh-profile\&Itemid $=90 \&$ lang $=$ en

DOSH. (2012). Statistics of Department. Retrieved from http://www.dosh.gov.my/doshv2/index.php?option=com_phocadownload\&view=category\&id=9\&Itemid=1 41\&lang=en

Fernandez-Muniz, B., Montes-Peon, J. M., \& Vazquez-Ordas, C. J. (2007). Safety culture: Analysis of the Causal Relationships between Its Key Dimensions. Journal of Safety Research, 38, 627-641. http://dx.doi.org/10.1016/j.jsr.2007.09.001

Ismail, F., Harun, H., Ismail, R., \& Majid, M. Z. A. (2010). A Framework of Safety culture for the Malaysian 
Construction Companies: A Methodological Development. Pertanika Journal of Social Science and Humanities, 18(1), 45-54.

Ismail, F., Hashim, A. E., Ismail, R., \& Majid, M. Z. A. (2009). The Operationalisation of Safety Culture for the Malaysian Construction Organisations. International Journal of Business and Management, 4(9), 226-237.

Kerlinger, F. N. (1973). Foundations of Behavioral Research (2nd ed.). Harcourt College Publishers.

Krause, T. R., \& Weekley, T. (2005, November). Safety Leadership: A Four-factor Model for Establishing a High Functioning Organization. Professional Safety, 34-40.

Martyn, S. (2008). Operationalization. Retrieved from http://www.experiment.resources/operationalization.html

Mohd Saidin, M., Abdul Hakim, M., Sulaiman, K., Zakaria, M. Y., Wan Yusoff, W. M., \& Ahmadon, B. (2006). Pembangunan Budaya Keselamatan dalam Industri Pembinaan, proceedings of the International Conference on Construction Industry 2006 (ICCI 2006). June 21-25. Padang, Sumatera Barat.

Nunally, J. C. (1978). Psychometric Theory. New York: McGraw-Hill.

Sarantakos, S. (1998). Social Research (2nd ed.). Palgrave Publisher.

Schneider, B. (1990). Organizational Climate and Culture. Jossey-Bass Publisher.

Soehod, K., \& Laxman, L. (2007). Law on Safety and Health in Malaysia. Fakulti Pengurusan dan Pembangunan Sumber Manusia, Universiti Teknologi Malaysia.

Tustin, C. O. (1992). The Operationalisation of Service Quality Using Quality Dimensions and Expectation / Perception Gap Analysis. Published Dissertation (PhD), Arizona State University.

Zainudin, A. (2010). Research Methodology for Business \& Social Science (2nd ed.). UPENA.

\section{Copyrights}

Copyright for this article is retained by the author(s), with first publication rights granted to the journal.

This is an open-access article distributed under the terms and conditions of the Creative Commons Attribution license (http://creativecommons.org/licenses/by/3.0/). 